\title{
Techno-Ergonomical Evaluation of Sickles for the Farmers of Odisha
}

\author{
Gayatri Mohanty, Dr. S K Mohanty \\ Dept of Farm Machinery and Power, College of Agricultural Engineering and Technology, OUAT, Bhubaneswar -751003
}

\begin{abstract}
Awkward posture, repetitive movement and forceful exertions are the major cause of muscular skeletal disorder in the agricultural activities. Harvesting of rice with local available sickle is most common activities in Odisha. The work stress and physiological variance among the male and female agricultural workers of 10 agro-climatic zone of Odisha have been studied. The demographic information and responses were collected from the workers. It was also observed that injuries of finger cut are most common among workers during the harvesting season while harvesting with local sickles. Keeping this in view Sickles have been collected from the ten different agro-climatic zones of Odisha and its performance was evaluated. The weight of the sickle varied in the range of $62 \mathrm{gm}$ to $349 \mathrm{gm}$. The size of the sickle observed to vary from one agro-climatic zone to other. The mean value of age, weight, body surface area, resting heart rate and resting oxygen consumption of male and female workers observed to be 32.3 and 31.1 years, 51.8 and $51.7 \mathrm{~kg}, 1.56 \mathrm{~m}^{2}$ and $1.42 \mathrm{~m}^{2}, 76.5$ and 70.3 beats $/ \mathrm{min}, 0.2$ and $0.19 \mathrm{l} / \mathrm{min}$ for male and female agricultural workers respectively. The stature, vertical reach, hand length, palm length, hand breadth across thumb, hand breadth were measured for both male and female agricultural workers. The length of the sickle varies from 32 to $42.5 \mathrm{~cm}$ for the sickles, collected from different agricultural zone of Odisha. The sickles along with the improved sickle were evaluated ergonomically. The working heart rate during operation was observed to be in the range of 110 to 118 beats/min for male and 109 to 111 beats/min for female where as the working oxygen consumption rate was recorded in the range of 0.56 to $0.73 \mathrm{l} / \mathrm{min}$ for male and 0.52 to $0.71 \mathrm{l} / \mathrm{min}$ for female agricultural workers while working with local sickles. The harvesting capacity of the local sickles varied on the range of 64 to $89 \mathrm{sq} \mathrm{m} /$ hour for male and 61 to 81 for female agricultural workers and with one with improved sickle it was recorded 60.2 to $66.5 \mathrm{sq} \mathrm{m} / \mathrm{h}$. But while comparing the heart rate and OCR data lowers physiological parameters were recorded with improved sickle against local sickles. The continuous working time observed to be 26 minutes against 36 minutes in case of improved sickle. However the workers preferred improved sickles over local sickles due to its better handle design, serrated cutting surface and lower weight. The local manufacturer / blacksmiths may be trained to produce such type of sickle for higher efficiency, minimizing accidents and reduction of drudgery.
\end{abstract}

Keywords: Ergonomics, Sickle, Working heart rate, Oxygen consumption rate.

\section{Introduction}

The sickle is one of humanity's oldest tools. Traditional harvesting requires almost 25 per cent of the total labour requirement of the cultivation of any crop. It is reported that the labour requirement for harvesting of rice by sickle is 240 man-h/ha (Mondol, 1997 and Shakoor and Salim , 2005). Working capacity is the highest in traditional harvesting with an average value of $111.10 \mathrm{~h} / \mathrm{ha}$ (Alizadeh and Allahah , 2013) Still widely used, it hasn't changed in design very much since ancient times - a (usually) curved blade with a handle that was used to cut, or reap, grain. Sickle with two types of cutting edge, i.e., plain and serrated having narrow serration with depth of about $1 \mathrm{~mm}$ are being used at farm by the farmers in the country. Of these, use of plain sickle is more because serrated sickle is mostly preferred for wheat harvesting. It is known that serrated sickle involves frictional force while plain sickle involves shearing force. Further, this type of serrated sickle has been improved by different research organizations and industry with better serration so that it could be used for harvesting more crops. Presently harvesting of paddy, wheat, soybean, gram etc are also being performed by mechanical harvester and combines. The mechanical harvesters covers only 5 per cent of the total harvested area, but rest 95 per cent are still done by sickle. The performance of any machine especially manually operated ones could be considerably improved if ergonomic aspects are given due consideration (Gite, 1993). Hence, there is an urgent need to study the ergonomic aspects in detail to quantify the drudgery involved in agricultural operations. Human energy measurements are important because whenever the physical capacity of a person is exceeded, it is bound to cause considerable fatigue and reduction in the efficiency of operation. Thus, investigations on ergonomic evaluation of farm equipment can provide a rational basis for recommendation of methods and improvement in equipment design for more output and safety.

\section{Agro-Ecological Zoning (ACZ):}

\section{Materials and methods}

It refers to the division of an area of land into smaller units, which have similar characteristics related to land suitability, potential production and environmental impact. Alternatively, an Agro-ecological Zone is a land resource mapping unit, defined in terms of climate, landform and soils, and/or land cover, and having a specific range of potentials and constraints for land use. Odisha has been divided into 10 Agro-Climatic Zones based on the basis of soil structure, humidity, elevation, topography, vegetation, rainfall and other Agro- Climatic factors. The details of agro-climatic zone are given below in Table no 1 . 
Table 1: Agro-climatic zones of Odisha

\begin{tabular}{|c|c|c|c|}
\hline Sl. No & Name of the Agro-climatic zone & Name of the districts & Zone name \\
\hline 1 & $\begin{array}{lll}\text { North } & - & \text { Western }\end{array}$ & Sundargarh, Deogarh & $\mathrm{ACZ}_{1}$ \\
\hline 2 & North Central Plateau & Mayurbhanj, & $\mathrm{ACZ}_{2}$ \\
\hline 3 & North Eastern Coastal Plain & Balasore, & $\mathrm{ACZ}_{3}$ \\
\hline 4 & East and South Eastern Coastal Plain & $\begin{array}{lcr}\text { Cuttack, } & \text { Jagatsingpur, } & \text { Kendrapada, } \\
\text { Puri, } & \text { Khurdha, } & \text { Nayagarh }\end{array}$ & $\mathrm{ACZ}_{4}$ \\
\hline 5 & North Eastern Ghat & $\begin{array}{lll}\text { Ganjam, } & \text { Gajapati, } & \text { Rayagada, } \\
\text { Phulbani } & & \\
\end{array}$ & $\mathrm{ACZ}_{5}$ \\
\hline 6 & Eastern Ghat High Land & Nowragpur & $\mathrm{ACZ}_{6}$ \\
\hline 7 & South Eastern Ghat & Malkangiri & $\mathrm{ACZ}_{7}$ \\
\hline 8 & Western Undulating Zone & Kalahandi, & $\mathrm{ACZ}_{8}$ \\
\hline 9 & Western Central Table Land & $\begin{array}{l}\text { Bolangir, Sonepur, Boudh, Sambalpur, } \\
\text { Baragarh, }\end{array}$ & $\mathrm{ACZ}_{9}$ \\
\hline 10 & Mid Central Table Land & Dhenkanal, Angul & $\mathrm{ACZ}_{10}$ \\
\hline
\end{tabular}

Selection of Sickles:

One sickle is collected from each agro-climatic zone. So total 10 numbers of sickles are collected for our study. The dimensions of all the selected sickles are measured and given in Table no 2.

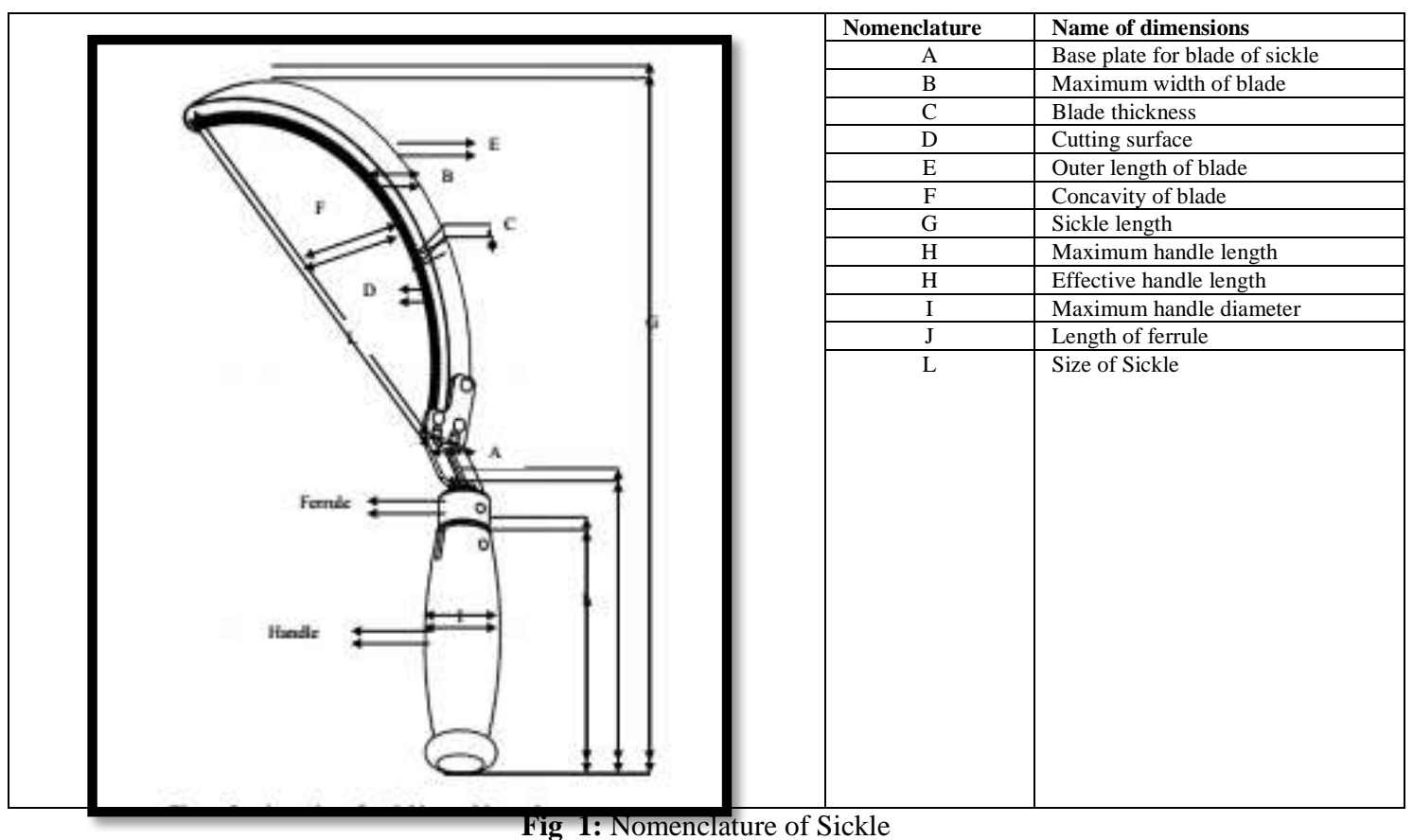

Table 2: Dimensions of selected Sickles

\begin{tabular}{|c|c|c|c|c|c|c|c|c|c|c|}
\hline \multirow{2}{*}{ Dimensions } & \multicolumn{10}{|c|}{ Agro climatic zones } \\
\hline & $\mathrm{ACZ}_{1}$ & $\mathrm{ACZ}_{2}$ & $\mathrm{ACZ}_{3}$ & $\mathrm{ACZ}_{4}$ & $\mathrm{ACZ}_{5}$ & $\mathrm{ACZ}_{6}$ & $\mathrm{ACZ}_{7}$ & $\mathrm{ACZ}_{8}$ & $\mathrm{ACZ}_{9}$ & $\mathrm{ACZ}_{10}$ \\
\hline Weight, $\mathrm{g}$ & 220 & 122 & 126 & 62 & 339 & 230 & 120 & 250 & 349 & 280 \\
\hline Outer length of blade, $\mathrm{cm}$ & 33.5 & 29 & 25.5 & 24 & 46 & 38.5 & 27 & 34.5 & 46 & 40 \\
\hline Inner length of blade, $\mathrm{cm}$ & 21 & 26 & 21.5 & 20.5 & 28 & 23 & 23 & 27 & 32 & 30 \\
\hline Width of blade, $\mathrm{cm}$ & 3 & 2 & 2.5 & 1.7 & 2 & 2 & 2.8 & 3 & 2.5 & 3.1 \\
\hline Thickness of blade, $\mathrm{mm}$ & 6 & 1.5 & 2.5 & 1.5 & 3.5 & 3 & 3.5 & 4 & 5.5 & 4.5 \\
\hline Handle length, $\mathrm{cm}$ & 11 & 12.7 & 13.5 & 11 & 13.5 & 10.5 & 11.5 & 15.5 & 12 & 10.7 \\
\hline Handle circumference, $\mathrm{cm}$ & 10 & 9 & 9.5 & 9 & 11.5 & 13 & 10 & 10 & 10 & 10 \\
\hline Sickle length, $\mathrm{cm}$ & 32 & 34.5 & 38.5 & 32.5 & 41 & 32.5 & 35.5 & 42.5 & 40.5 & 40 \\
\hline
\end{tabular}

\section{Selection of subjects:}

Twenty subjects were selected having anthropometric dimensions conforming to statistical requirements from the ten Agro-Climatic Zone of Odisha. One male and one female subjects were selected from each agro-climatic zone. The studied values were compared with the existing anthropometric data The physiological characteristics of selected subjects are given in Table no 3. 
All the selected subjects for agronomical evaluation were ensured. It was also ensured that they were free from the influence of stimulants and had no cardiac disease. Prior to the test, their resting heart rate, oxygen consumption rate, blood pressure was measured. Their $\mathrm{VO}_{2 \max }$ was predicted to be at par with their age, body mass index(BMI) and body surface area (BSA) of the agricultural workers calibrated in the ergonomical laboratory of CAET. The anthropometric parameters of selected subjects $(\mathrm{N}=10)$ has been placed in table no 2 . The total no of 31 parameters of anthropometric and strength data of fifteen women subjects was measured with the help of integrated composite anthrpometer. The mean value of stature, vertical reach, vertical grip reach, acronomial height of Odisha workers was recorded lower than that of Indian agricultural worker. Keeping the design parameter into consideration, the $5^{\text {th }}, 95^{\text {th }}$ percentile value was also measured . The push and pull strength (both hands) was recorded for ergonomical interventions. The physiological parameters with anthropometric and strength data of male and female agricultural workers have been placed at table no 3 and 4 . The heart rate was measured with the help of polar heart rate monitor. The oxygen consumption rate was also evaluated with the help of $\mathrm{K}_{4} \mathrm{~B}_{2}$. The average value of working heart rate, working oxygen consumption rate for a period of $5^{\text {th }}$ to $20^{\text {th }}$ minute of continuous operation were placed in table no 5 and 6.

Localized discomfort during the operation of different sickles was measured by using scientific technique (Corlett and Bishop, 1976). In this technique the subject's body is divided into 27 regions . A body mapping similar to that was made up of with thermo cool to have a real and meaningful rating of perceived exertion of the subjects. The subject was asked to mention his discomforts that felt in his body parts starting from worst, second worst and so on. The subject was asked to fix the pins on the body parts in order of his exertion by putting one pin for maximum pain, two pins for next lower maximum pain and so on. The different body parts that were identified as extreme discomfort to zero discomfort represented the number of intensity levels of pain that were experienced in those parts. The number of intensity levels of pain experienced for manual weeding operation was taken as 6 comprising of extremely heavy, very heavy, heavy, moderately heavy, light and very light.

Table 3: Physiological parameters of selected subjects

\begin{tabular}{|c|c|c|c|c|c|c|c|}
\hline \multirow[t]{2}{*}{ SI no } & \multirow{2}{*}{$\begin{array}{l}\text { Physiological } \\
\text { Parameters }\end{array}$} & \multicolumn{3}{|l|}{$\operatorname{Men}(\mathrm{N}=10)$} & \multicolumn{3}{|c|}{ Women $(\mathrm{N}=10)$} \\
\hline & & Range & Mean & Standard Deviation & Range & Mean & Standard Deviation \\
\hline 1 & Age, Years & $19-44$ & 32.3 & 7.05 & $18-45$ & 31.1 & 8.0 \\
\hline 2 & Weight, $\mathrm{Kg}$ & $40-68$ & 51.8 & 5.6 & $45-59$ & 51.7 & 4.9 \\
\hline 3 & Height, $\mathrm{cm}$ & $148.8-180.2$ & 163.6 & 12.6 & $142.1-163$ & 152.3 & 7.6 \\
\hline 4 & $\mathrm{HR}_{\mathrm{rest}}$, beats/min & $72-81$ & 76.5 & 2.8 & $65-76$ & 70.3 & 3.2 \\
\hline 5 & $\mathrm{HR}_{\max }$, beats/min & $176-201$ & 190.2 & 8.2 & $176-200$ & 188.2 & 7.2 \\
\hline 6 & $\mathrm{VO}_{2}$ rest, $1 / \mathrm{min}$ & $0.18-0.26$ & 0.2 & 0.03 & $0.16-0.24$ & 0.19 & 0.02 \\
\hline 7 & $\mathrm{VO}_{2 \max }, 1 / \mathrm{min}$ & $1.81-2.32$ & 1.96 & 0.09 & $1.56-1.81$ & 1.71 & 0.08 \\
\hline 8 & $\mathrm{BSA}, \mathrm{m}^{2}$ & $1.42-1.76$ & 1.56 & 0.18 & $1.37-1.69$ & 1.42 & 0.1 \\
\hline 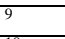 & $\mathrm{BMI}, \mathrm{Kg} / \mathrm{m}^{2}$ & $18.8-26.5$ & 23.3 & 0.8 & $20.5-23.25$ & 22.31 & 0.8 \\
\hline 10 & Experiences, yrs & $2-29$ & 19.3 & 4.8 & $2-27$ & 18.2 & 3.5 \\
\hline
\end{tabular}

The anthropometric data of selected subjects are measured. The details are shown in the Table 4.

Table 4: Anthropometric parameters of selected subjects

\begin{tabular}{|c|c|c|c|c|c|c|c|}
\hline \multirow[t]{4}{*}{ Sl no } & \multirow[t]{4}{*}{ Dimensions } & \multicolumn{6}{|c|}{ Odisha data } \\
\hline & & \multicolumn{3}{|c|}{ Male } & \multicolumn{3}{|c|}{ Female } \\
\hline & & \multirow{2}{*}{ Mean } & \multicolumn{2}{|c|}{ Percentile } & \multirow[t]{2}{*}{ Mean } & \multicolumn{2}{|c|}{ Percentile } \\
\hline & & & $5^{\text {th }}$ & $95^{\text {th }}$ & & $5^{\text {th }}$ & $95^{\text {th }}$ \\
\hline 1 & Weight, kg & 51.8 & 40.4 & 63.3 & 44.0 & 33.8 & 54.2 \\
\hline 2 & Stature, $\mathrm{cm}$ & 163.5 & 152.1 & 174.9 & 151.6 & 142.1 & 161.1 \\
\hline 3 & Vertical reach, $\mathrm{cm}$ & 209.7 & 194.5 & 224.9 & 190.1 & 177.3 & 202.8 \\
\hline 4 & Vertical grip reach, $\mathrm{cm}$ & 198.9 & 183.6 & 214.3 & 179.6 & 167.1 & 192.0 \\
\hline 5 & Span , cm & 172.3 & 158.5 & 186.1 & 158.3 & 142.6 & 174.1 \\
\hline 6 & Span akimbo ,cm & 89.7 & 80.8 & 98.6 & 80.9 & 71.8 & 90.0 \\
\hline 7 & Thumb tip reach , $\mathrm{cm}$ & 74.9 & 65.0 & 84.8 & 67.2 & 57.1 & 77.3 \\
\hline 8 & Shoulder grip length ,cm & 69.7 & 59.5 & 79.8 & 63.0 & 52.9 & 73.0 \\
\hline 9 & Wrist circumference, $\mathrm{cm}$ & 15.7 & 13.8 & 17.5 & 15.0 & 13.2 & 16.8 \\
\hline 10 & Grip diameter(inside), $\mathrm{cm}$ & 4.7 & 3.9 & 5.5 & - & - & - \\
\hline 11 & Grip diameter(outside), $\mathrm{cm}$ & 8.6 & 7.1 & 10.1 & - & - & - \\
\hline 12 & Middle finger palm grip diameter, $\mathrm{cm}$ & 3.0 & 2.5 & 3.4 & - & - & - \\
\hline 13 & Vertical grip reach sitting, $\mathrm{cm}$ & 120.7 & 109.8 & 131.7 & 107.5 & 98.4 & 116.7 \\
\hline 14 & Sitting height, $\mathrm{cm}$ & 84.8 & 77.4 & 92.2 & 78.9 & 70.2 & 87.7 \\
\hline 15 & Hand thickness at metacarpal III ,cm & 3.4 & 2.4 & 4.3 & 3.2 & 2.0 & 4.3 \\
\hline 16 & Maximum grip length, $\mathrm{cm}$ & 12.1 & 9.3 & 14.8 & 10.8 & 8.4 & 13.3 \\
\hline 17 & Hand length, $\mathrm{cm}$ & 18.0 & 16.0 & 20.0 & 16.4 & 14.5 & 18.2 \\
\hline 18 & Coronoid fossa to hand length, $\mathrm{cm}$ & 39.3 & 35.4 & 44.5 & 35.7 & 30.9 & 40.5 \\
\hline 19 & Forearm hand length, $\mathrm{cm}$ & 46.2 & 41.5 & 51.0 & 41.9 & 37.6 & 46.1 \\
\hline 20 & Elbow grip length, $\mathrm{cm}$ & 36.8 & 31.3 & 42.4 & 33.5 & 28.9 & 38.1 \\
\hline 21 & Hand breadth, $\mathrm{cm}$ & 7.6 & 6.1 & 9.2 & 6.9 & 5.4 & 8.4 \\
\hline 22 & Palm length, $\mathrm{cm}$ & 10.4 & 9.0 & 11.8 & 9.3 & 7.7 & 10.9 \\
\hline 23 & Hand breadth across thumb, $\mathrm{cm}$ & 9.7 & 8.0 & 11.5 & 8.9 & 7.2 & 10.7 \\
\hline 24 & Pull strength(left hand )sitting, $\mathrm{N}$ & 8.1 & 4.8 & 11.4 & 5.7 & 3.3 & 8.1 \\
\hline 25 & Pull strength (right hand)sitting, $\mathrm{N}$ & 8.4 & 5.0 & 11.9 & 5.8 & 3.2 & 8.5 \\
\hline 26 & Hand grip strength (left), N & 33.6 & 20.2 & 47.0 & 22.5 & 11.1 & 33.9 \\
\hline 27 & Hand grip strength (right), $\mathrm{N}$ & 32.6 & 19.6 & 45.5 & 20.7 & 11.3 & 30.2 \\
\hline
\end{tabular}


Techno-Ergonomical Evaluation implementation of a Sickle for the farmers of Odisha

Table no 5: Physiological parameters of selected male subjects $(\mathrm{N}=10)$

\begin{tabular}{|c|c|c|c|c|c|c|c|c|c|c|}
\hline \multirow[t]{2}{*}{ Particulars } & \multicolumn{10}{|c|}{ Agro climatic zones } \\
\hline & $\mathrm{ACZ}_{1}$ & $\mathrm{ACZ}_{2}$ & $\mathrm{ACZ}_{3}$ & $\mathrm{ACZ}_{4}$ & $\mathrm{ACZ}_{5}$ & $\mathrm{ACZ}_{6}$ & $\mathrm{ACZ}_{7}$ & $\mathrm{ACZ}_{8}$ & $\mathrm{ACZ}_{9}$ & $\mathrm{ACZ}_{10}$ \\
\hline $\mathrm{HR}_{\text {rest }}$, beats/min & 74 & 72 & 73 & 70 & 80 & 75 & 72 & 77 & 82 & 78 \\
\hline WHR, beats/min & 113 & 112 & 114 & 110 & 117 & 113 & 110 & 114 & 118 & 115 \\
\hline$\Delta \mathrm{HR}$, beats $/ \mathrm{min}$ & 39 & 40 & 41 & 40 & 37 & 38 & 38 & 37 & 36 & 37 \\
\hline $\mathrm{VO}_{2 \text { rest } . / \mathrm{min}}$ & 0.20 & 0.18 & 0.19 & 0.18 & 0.22 & 0.20 & 0.18 & 0.21 & 0.23 & 0.21 \\
\hline $\mathrm{VO}_{2 \text { work, } 1 / \min }$ & 0.69 & 0.56 & 0.57 & 0.70 & 0.72 & 0.68 & 0.59 & 0.63 & 0.73 & 0.71 \\
\hline $\mathrm{VO}_{2 \max , 1 / \min }$ & 1.82 & 1.85 & 1.82 & 1.89 & 1.91 & 2.1 & 2.2 & 1.72 & 1.90 & 1.74 \\
\hline RCWL, $\%$ of $\mathrm{VO}_{2 \max }$ & 37.9 & 30.2 & 31.3 & 37 & 37.6 & 32.3 & 26.8 & 36.6 & 38.4 & 40.8 \\
\hline EER , kJ/min & 14.4 & 11.7 & 11.9 & 14.6 & 15 & 14.2 & 12.3 & 13.1 & 15.2 & 14.8 \\
\hline Bending angle, degrees & $90^{\circ}$ & $102^{0}$ & $83^{0}$ & $93^{0}$ & $98^{0}$ & $89^{0}$ & $94^{0}$ & $99^{0}$ & $97^{0}$ & $104^{0}$ \\
\hline Body parts discomfort score & 3.0 & 3.0 & 4.5 & 3.5 & 5.5 & 3.5 & 3.0 & 3.5 & 5.5 & 4.5 \\
\hline Harvesting capacity, $\mathrm{m}^{2} /$ hour & 64 & 83 & 73 & 76 & 78 & 71 & 68 & 82 & 75 & 89 \\
\hline Continuous operation time, $\min$ & 60 & 71 & 68 & 65 & 67 & 74 & 65 & 78 & 72 & 80 \\
\hline
\end{tabular}

Table no 6: Physiological parameters of selected female subjects $(\mathrm{N}=10)$

\begin{tabular}{|c|c|c|c|c|c|c|c|c|c|c|}
\hline \multirow[t]{2}{*}{ Particulars } & \multicolumn{10}{|c|}{ Agro climatic zones } \\
\hline & $\mathrm{ACZ}_{1}$ & $\mathrm{ACZ}_{2}$ & $\mathrm{ACZ}_{3}$ & $\mathrm{ACZ}_{4}$ & $\mathrm{ACZ}_{5}$ & $\mathrm{ACZ}_{6}$ & $\mathrm{ACZ}_{7}$ & $\mathrm{ACZ}_{8}$ & $\mathrm{ACZ}_{9}$ & $\mathrm{ACZ}_{10}$ \\
\hline $\mathrm{HR}_{\text {rest }}$, beats/min & 72 & 70 & 71 & 69 & 78 & 73 & 71 & 76 & 80 & 77 \\
\hline WHR, beats/min & 112 & 111 & 112 & 109 & 115 & 110 & 109 & 113 & 117 & 113 \\
\hline$\Delta \mathrm{HR}$, beats $/ \mathrm{min}$ & 40 & 41 & 41 & 40 & 37 & 47 & 36 & 37 & 37 & 36 \\
\hline $\mathrm{VO}_{2 \text { rest }, 1 / \min }$ & 0.19 & 0.16 & 0.18 & 0.17 & 0.2 & 0.2 & 0.15 & 0.2 & 0.19 & 0.2 \\
\hline $\mathrm{VO}_{2 \text { work, } 1 / \text { min }}$ & 0.65 & 0.52 & 0.55 & 0.68 & 0.7 & 0.65 & 0.54 & 0.61 & 0.71 & 0.69 \\
\hline $\mathrm{VO}_{2 \max , 1 / \min }$ & 1.72 & 1.83 & 1.80 & 1.85 & 1.86 & 1.66 & 1.65 & 1.68 & 1.72 & 1.69 \\
\hline RCWL, $\%$ of $\mathrm{VO}_{2 \max }$ & 37.7 & 28.4 & 30.5 & 36.7 & 37.6 & 39.1 & 32.7 & 36.3 & 41.2 & 40.8 \\
\hline $\mathrm{EER}, \mathrm{kJ} / \mathrm{min}$ & 13.5 & 10.8 & 11.5 & 14.2 & 14.6 & 13.5 & 11.2 & 12.7 & 14.8 & 14.4 \\
\hline Bending angle, degrees & $85^{0}$ & $85^{0}$ & $80^{\circ}$ & $81^{0}$ & $83^{0}$ & $83^{0}$ & $88^{0}$ & $91^{0}$ & $87^{0}$ & $98^{0}$ \\
\hline $\begin{array}{l}\text { Body parts discomfort score (10 point } \\
\text { scale) }\end{array}$ & 3.0 & 3.0 & 4.5 & 3.5 & 5.5 & 3.5 & 3.0 & 3.5 & 5.5 & 4.5 \\
\hline Harvesting capacity, $\mathrm{m}^{2} / \mathrm{ha}$ & 61 & 80 & 71 & 72 & 73 & 65 & 64 & 75 & 70 & 81 \\
\hline Continuous operation time, $\min$ & 76 & 91 & 77 & 79 & 80 & 78 & 78 & 85 & 80 & 95 \\
\hline
\end{tabular}

\section{Results and Discussions}

Twenty subjects in the age group of 18-45 (Nag et.al.)years were selected for the evaluated of local available sickles in 10 agro-climatic zone of Odisha shown in Table no 1.10 different sickles used for harvesting of Rice were collected from the farmers for taking of the evaluation. Different parameters of the selected sickles have been placed in table no 2. The weight of sickles varies in the range of 62 to 349 gms. The length of sickle was observed maximum $42.5 \mathrm{~cm}$ in ACZ 8 (Kalahandi, Nuapada). The size and weight of sickle varied as per the anthropometric and strength parameters of the workers in Odisha. twenty numbers of subjects comprising of male and female .Ten numbers were selected for ergonomic evaluation of sickle. The mean value of age and weight were observed to be $32.3 \pm 7.05$ years, $51.8 \pm 5.6 \mathrm{~kg}$ for male and $31.3 \pm 8.0$ years, $51.7 \pm 4.9 \mathrm{~kg}$ for women workers. The heart rate and oxygen consumption rate at rest and during work was observed with the help of heart rate monitor and $\mathrm{K}_{4} \mathrm{~B}_{2}$ respectively. The BSA was record $1.56 \pm 0.18$ for male workers and $1.42 \pm 0.12$ for women workers. The detail physiological parameters of men and women workers are placed table no 3 . The anthropometric and strength parameters using integrated anthropometric composite is placed in table no 4 . The value of stature, vertical reach, vertical grip reach, maximum hand length, hand breadth, pull strength (right hand), hand strength (right hand) was observed for men and women workers in different agro climatic zone. The mean value of height and weight of male workers were observed $163.5 \mathrm{~cm} 51.8 \mathrm{~kg}$ respectively which is more than female workers. The heart rate at rest was observed to be 72 to 82 for male and 70 to 80 female workers in different agro climatic zone of Odisha. The $\mathrm{VO}_{2}$ max was predicted to 1.72 to $2.21 / \mathrm{min}$ for male and 1.65 to $1.86 \mathrm{l} / \mathrm{min}$ for female workers. The WHR was observed to be 118 in $\mathrm{ACZ}_{9}$ and lowest in $\mathrm{ACZ}_{4}$ and $\mathrm{ACZ}_{7}$ for male. The weight of sickle $349 \mathrm{gms}$ in $\mathrm{ACZ}_{9}$ which is highest and $62 \mathrm{gm}$ in ACZ4. The higher physiological value may be due to reason that with increase in weight of sickle, the HR and OCR increases. Similar results have also been observed by Sujata et.al., 1998 , while measuring the heart rate during harvesting sickles with 23 female workers with a mean age of $33.35 \pm 12.2$. 


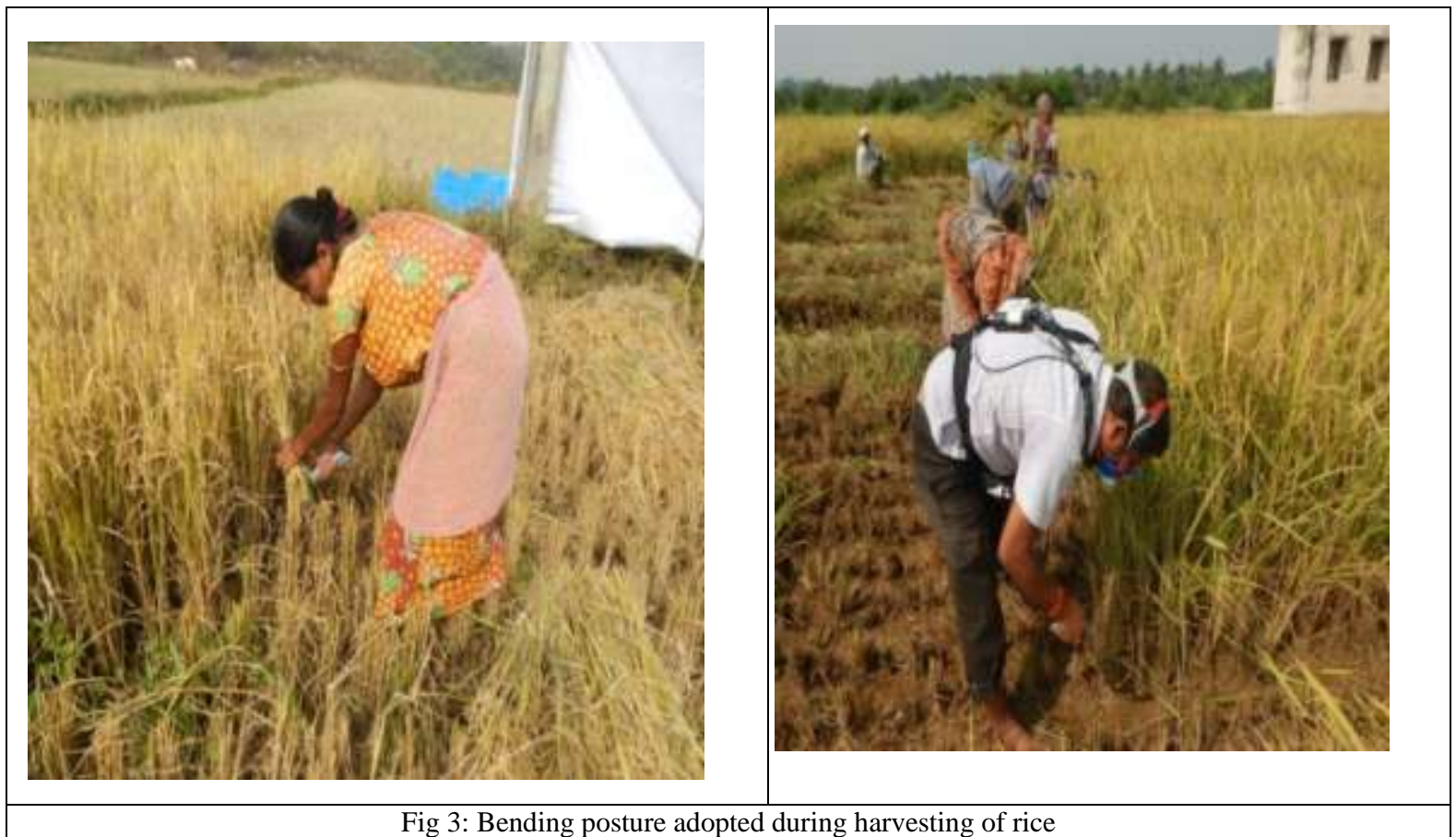

During harvesting operation, the bending posture was adopted. The bending angle increases with stature of men and women subjects. It was observed that, subjects with high stature, $104^{0}$ highest in $\mathrm{ACZ}_{10}$, followed by $102^{0}$ in $\mathrm{ACZ}_{2}$ and lowest $83^{\circ}$ in $\mathrm{ACZ}_{3}$. While comparing bending angle with stature, it was observed that the stature of $\mathrm{ACZ}_{10}, \mathrm{ACZ}_{2}$, $\mathrm{ACZ}_{3}$ decreases. Using a 10 point Visual Analog Discomfort (VAD) scale, the body parts discomfort 5.5 in $\mathrm{ACZ}_{5}$ and $\mathrm{ACZ}_{9}$ and lowest in $\mathrm{ACZ}_{1}, \mathrm{ACZ}_{2}$ and $\mathrm{ACZ}_{7}$. Adopting the bending posture , the harvesting capacity was varied from 71 to $89 \mathrm{~m}^{2} / \mathrm{h}$. So that to cover 1 acre of land 44 hours or 7.2 man-hours per acre is required for male . The body parts filling maximum discomfort was observed in waist, thigh, shoulder, right hand for both men and women workers. The relative cost of work load was observed to maximum 40.8 per cent of male workers in $\mathrm{ACZ}_{10}$ female workers 38.4 per cent in $\mathrm{ACZ}_{1}$ this indicated the fatigue of the workers. It is also observed that with increase in weight of a sickle the relative cost of work load also increases.

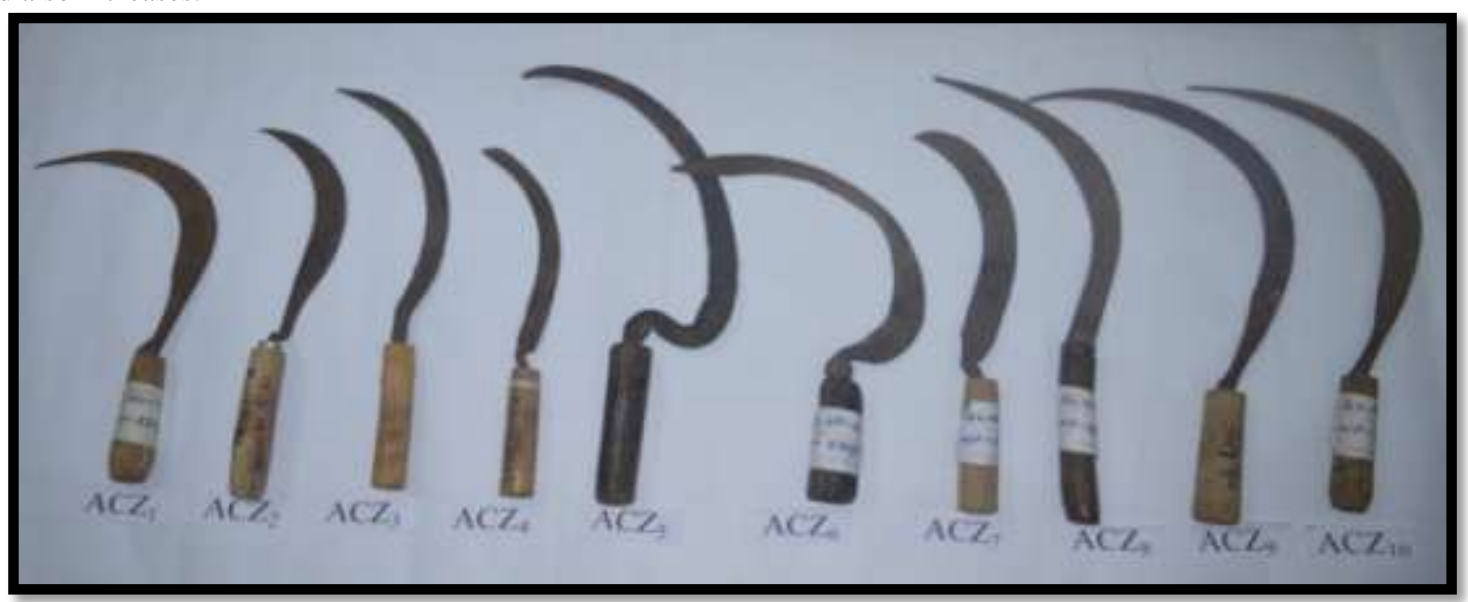

Fig 4: Figure of Sickles from ten agro-climatic zones of Odisha

Basing upon the harvesting capacity and physiological parameters of the selected subjects, a suitable sickle was recommended for the agricultural male and female workers. The weight of sickle should be in the range of 220 to 250 gram and length of sickle should made in the range of 32 to $36 \mathrm{~cm}$. Keeping the hand anthropometric parameters like hand grip diameter, hand breadth across thumb , hand length , middle finger palm , grip diameter, pull strength (right hand) sitting of the subjects, the handle should be made of plastic or wood of 10 to $12 \mathrm{~cm}$ size with a handle circumference of 10 to $11 \mathrm{~cm}$. As the sickle is to be operated by both male and female agriculture workers $95^{\text {th }}$ percentile middle finger palm grip diameter $(34 \mathrm{~mm})$ and $5^{\text {th }}$ percentile grip diameter (inside) of female workers $(30 \mathrm{~mm})$ should be used for designing a sickle. As per the strength data the $5^{\text {th }}$ percentile value of pull force with right hand in sitting posture for female is $40 \mathrm{~N}$. Applying the 30 per cent limit, the force limit for sickle (for pull force) works out to be $12 \mathrm{~N}$. The size of the sickle should be made in such a way that the worker can harvest continuously for 70 to 80 minutes without rest as a result the efficiency will be increased with minimum drudgery. 


\section{Conclusion}

Sickle is used for harvesting rice in different agro climatic zone of Odisha. The local sickle consists of a plain blade, ferrule and wooden handle. The cutting of rice bundle is mostly done by sawing action as well as by impact or pulling action. Bending posture is adopted to harvest the rice. The weight of sickle varied in the range of 62 to $349 \mathrm{gm}$. The working heart rate and oxygen consumption rate of male workers was recorded in the range of 110 to 118 beats/min and 0.56 to $0.73 \mathrm{l} / \mathrm{min}$ respectively for male worker and 109 to 111 beats/min and 0.52 to $0.71 \mathrm{l} / \mathrm{min}$ respectively for female workers.

The continuous working time varied in the range of 60 to 80 minutes for male workers and 76 to 95 minutes for female workers .Keeping agro climatic and mechanical parameters, a suitable sickle is recommended for the farmers of Odisha. The handle grip length should not exceed $5^{\text {th }}$ percentile value of hand length of female workers which is $145 \mathrm{~mm}$. Therefore a length of $120 \mathrm{~mm}$ is recommended for sickle handle. The weight of sickle should also vary in the range of 220 to 250 gram for ease operation and reduction of drudgery.

\section{References}

[1] Alizadeh , M.R. and A. Allameh. 2013. Evaluating rice losses in various harvesting practices. International Research Journal of Applied and Basic Sciences, 4 (4:894-901)

[2] Corlett, E. N. and Bishop, R. P. 1976. A technique for assessing postural discomfort. Ergonomics, 19:175-182

[3] Gite, L.P. 1993. Ergonomics in Indian Agricultural. A review paper presented in the International Workshop on Human and Draught animal powered crop production held on January 19-22 at Harare (Zimbabwe).

[4] Gite , et.al. , 2009. Anthropometric and strength data of Indian agricultural workers for farm equipment design, Central Institute of Agricultural Engineering, Bhopal.

[5] Tiwari R. et.al.2013. Ergonomic evaluation and economics of improved harvesting technology for farm women. International Journal of Scientific Research, Vol (2):554-557

[6] Mc Ardle,W.D .;Katch, F. I. And Katch, V. L. 2001. Exercise Physiology, $5^{\text {th }}$ edition. Lippincott Willams and Wilkins publication.

[7] Mondol , M. R. A. 1997 . Performance evaluation and improvement of power tiller mounted ce eal reaper, MS thesis, Department of Farm Power and Machinery, Bangladesh Agricultural University, Bangladesh. 